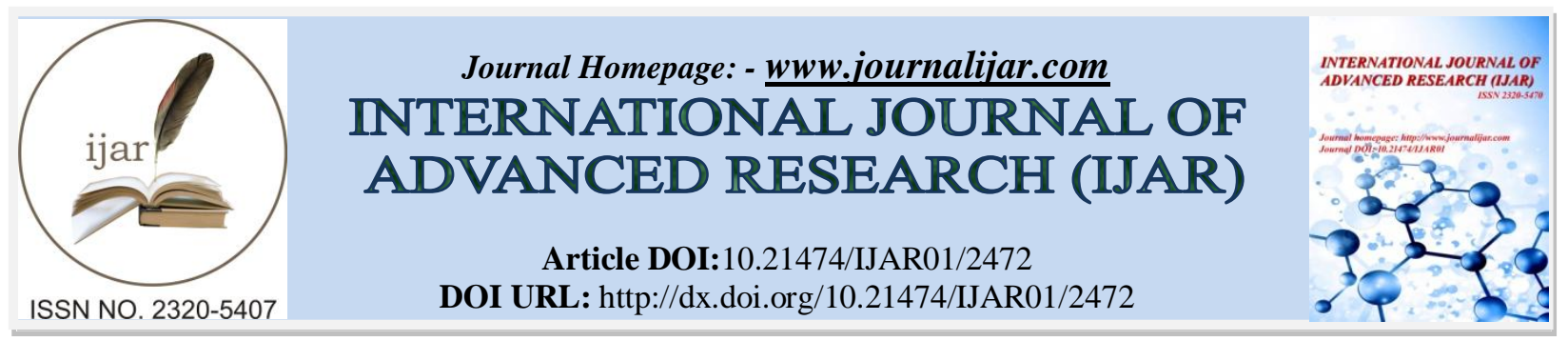

RESEARCH ARTICLE

\title{
PLANKTON VARIABILITY IN RELATION TO SOME ENVIRONMENTAL FACTORS IN THE IMESSOUANE BAY, MOROCCO.
}

\author{
E. Ait-Talborjt, N. Hafidi, J. Hermas, L. Ez-Zaher and H. ElOuizgani \\ Laboratory of Oceanography and Fisheries, Faculty of Science Agadir, University Ibn Zohr, Morocco.
}

\section{Manuscript Info}

\section{Manuscript History}

Received: 23 October 2016

Final Accepted: 21 November 2016

Published: December 2016

Key words:-

Copepods, Bay of Imessouane,

Zooplankton; Phytoplankton, Oithona,

Nitrites, Thermocline.

\section{Abstract}

Our present work aims to evaluationof the richness of plankton communities and the influence of some physicochemical factors on plankton in the Imessouane Bay. The Copepods constitute more than $80 \%$ of the zooplankton communities. The phytoplankton species have maximum abundance during the summer, especially at the end of June where there are blooms of some species of harmful phytoplankton (Ceratiumfusus, Prorocentrummicans, Protoperidiniumdepressum, Dictyocha fibula).The Nitrites recorded a maximum level (July 21st) at the 10 meters depth. Low abundances of plankton populations are recorded at this depth. Above this area, high abundances of some copepod species are recorded. These results seem to be an indication that brings us to the phenomenon of surface thermocline. The canonical analysis of the correspondences allows structuring the zooplankton communities into three different groups. The first group is more abundant in the summer period ( clausocalanussp, centropagestypicus, temorastylifera).The second group present throughout the study period (paracalanusparvus, oncaeavenusta, acartiaclausi, jellyfish andsiphinophore). The third group has an affinity for nutrients (Euterpinaacutifrons and Evadne)

Copy Right, IJAR, 2016,. All rights reserved.

\section{Introduction:-}

The bay of Imessouane is an area that presents an important biological richness and the great ecological and economic Value [1].This bay was the object of several scientific researches which regarded this zone as the heart of the upwelling [2]. This phenomenon therefore ensures the development of the entire food web [3]. Moreover the spatial and temporal variability of upwelling along the pelagic ecosystem of the Moroccan Atlantic coast [4],is the source of physical and biological phenomena that govern the dynamics of marine plankton organisms. The species of plankton communities are most affected by these changes. The transmission of the effect of these variations relationships in the food chain generates fluctuations in fish stocks[5]. The comprehension of the marine ecosystem is not quite simple due to its complexity, both functionally and constitutionally. Plankton plays an important role in the understanding of this ecosystem. Phytoplankton and zooplankton take placethe trophic levels 1, 2, 3, and 4 important parts of the biological production [6]. Considering the importance of plankton communities in the marine ecosystem, our present work aims to evaluation of the richness of plankton communities and the influence of some physicochemical parameters on plankton in the Imessouane Bay.

Corresponding Author:-E. Ait-Talborjt.

Address:-Laboratory of Oceanography and Fisheries, Faculty of Science Agadir, University Ibn Zohr, Morocco. 


\section{Materials and Methods:-}

The study was done on samples taken at the Imessouane bay at three stations: S1 (-9 49 ' ' $58^{\prime} \mathrm{W}, 30^{\circ} 50$ ' $\left.20 \mathrm{~N}\right)$, S2 ($\left.9^{\circ} 49^{\prime \prime} 30^{\prime} \mathrm{W}, 30^{\circ} 49^{\prime}{ }^{\prime} 22^{\prime} \mathrm{N}\right)$ and S3 (-9 $49^{\prime} 83^{\prime}$ 'W, 30 49'71'’ N) (Figure. 1), during May, June and July. For each station, vertical samplings were made at a depth of $10 \mathrm{~m}$ for 10 minutes using standard plankton nets of different mesh $(100 \mu \mathrm{m}, 200 \mu \mathrm{m}$ and $500 \mu \mathrm{m})$.For quantitative samples of zooplankton and phytoplankton, they were made with a bottle of Niskin two liters over the same depth $(10 \mathrm{~m})$. The samples were fixed in formaldehyde $(5 \%)$, and the identification of plankton species were made on an inverted microscope (Olympus ULWCD0.30). The plankton identification based on morphological criteria provided by various determination keys collections. The physicochemical parameters (temperature, salinity, conductivity) were measured directly in the field using a conductivity meter (T.W.LF18, measuring cell Tetracon 325). Dissolved oxygen was measured by the Winkler method (Aminot and al., 1983). The samples for nutrient analysis N-N2O and PO4 were taken by the bottle Niskin at the 10 meter of the depth.

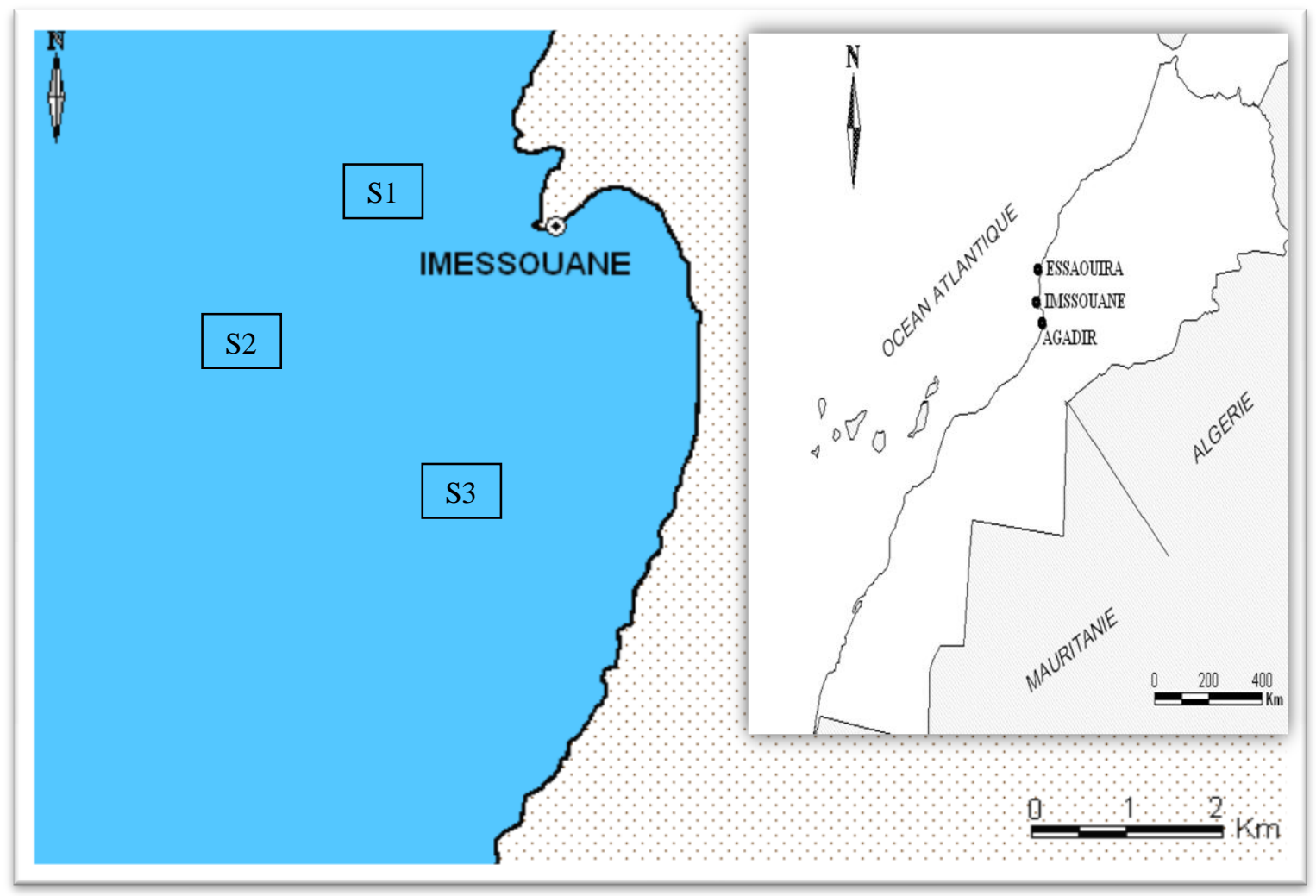

Figure 1:- Location of sampling stations (MapInfo)

\section{Statistical Treatment:-}

Two statistical tests were used for the analysis of our results CAP and CCA, the Component Analysis Principal (CAP) is a very effective method for the analysis of quantitative data. The Canonical Correspondence Analysis (CCA) connects the abundances of species to environmental variables [7].

\section{Results and Discussion:- Physicochemical parameters:- \\ Temperature:-}

The temperature is one of the important factors that is involved in the regulation of many biological processes at the planktonic organisms (growth, respiration ...). During our study the values of the temperature ranges between 21 and $16^{\circ} \mathrm{C}$. Low temperatures were recorded in June $\left(16^{\circ} \mathrm{C}\right)$. It is noted that at the end of spring there is a considerable reduction in the temperature and that at the beginning of the summer there is a remarkable increase. (Figure.3) 


\section{Dissolved oxygen:-}

Dissolved oxygen is the product of photosynthesis achieved by the phytoplankton. It constitutes a decreasing gradient with the depth[8]. We note dissolved oxygen levels that vary between 3 and $5,8 \mathrm{mg} / 1$ in our study sites. The lowest values in the three stations were recorded on June 30th (3mg / 1 in the first station). However strong values (>5mg/l) were recorded on July 21 st (Figure.3).

\section{Salinity:-}

The salinity is one of the abiotic factors that go into the determination of the structure of planktonic populations. It represents, probably in conjunction with the resources, a critical and selective parameter for the diversity and dynamics of plankton communities [9]. The values of salinity in our study site ranged between 35 and $36.9 \%$. We note recording a lower value at the third station $(35 \%$ ) on May 19th. While important values were recorded in the same day $(36 \%$ in the second station. (Figure. 3)

\section{Nitrites:-}

The nitrites concentrations present low values throughout the study period, except for July 21st, one recorded more important contents in the three stations (between 3.5 and 8,4mg/l). (Figure. 3)

According to Harris (1959)[10], the regeneration of the nitrogen of sea water can be done by, the excretion of nitrogenous waste products of metabolism (urea), by the zooplankton and the fish. Redfield and Keys (1938) [11]showed the existence of a strong correlation between areas rich in zooplankton or fishes and areas rich in mineral nitrogen. Krause (1964) [12]also reported that 15 to 30 minutes after the death of marine organisms, $30 \%$ of their nitrogen is rapidly released into the environment.

The important nitrogen values were recorded on July 31st could have a relationship with the presence of large numbers of fish during this date, and strong fishing on the fish species Scomberjaponicus in this site. According to the records of the National Office of Fisheries, the site had over a week before the release of July 21st, an important activity and continued fishing of this species, this activity generates intense organic rejections in the form of dead fishes or of the fish scraps rejected on the level of this site. By studying the speed and the direction of the wind resulting from satellite pictures NASA, during and before this date (July 21st), show that the direction is from the coast toward the offshore.This can explain the transfer of nitrogen resulting from the organic matter of fishes rejected to the level of our site (Figure.4).

\section{Orthophosphate:-}

In our study site, the contents of ortho-phosphates vary between 1.6 to $0.6 \mathrm{mg} / 1$. In May a maximum value was recorded $(1.6 \mathrm{mg} / \mathrm{l})$ in the station 2 . The month of June is known of great reduction in two stations 1 and 2 . In the station 3 thelow values were recorded during the study period (Figure. 3 ). 


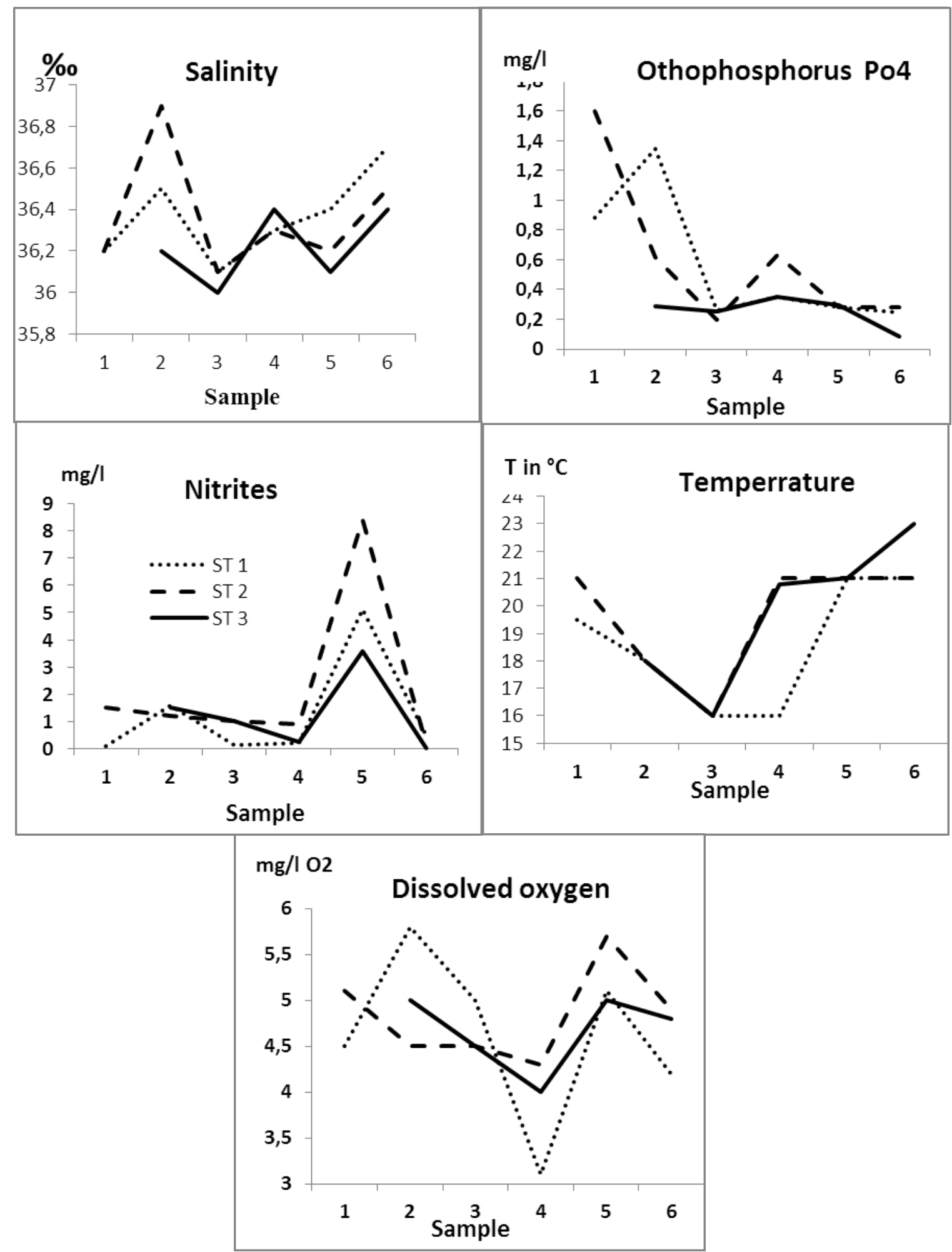

Figure 3:- Spatiotemporal evolution of salinity, temperature, dissolved oxygen, $\mathrm{PO} 4$ and $\mathrm{NO} 2$ waters of the Imessouane bay, during the study period. 


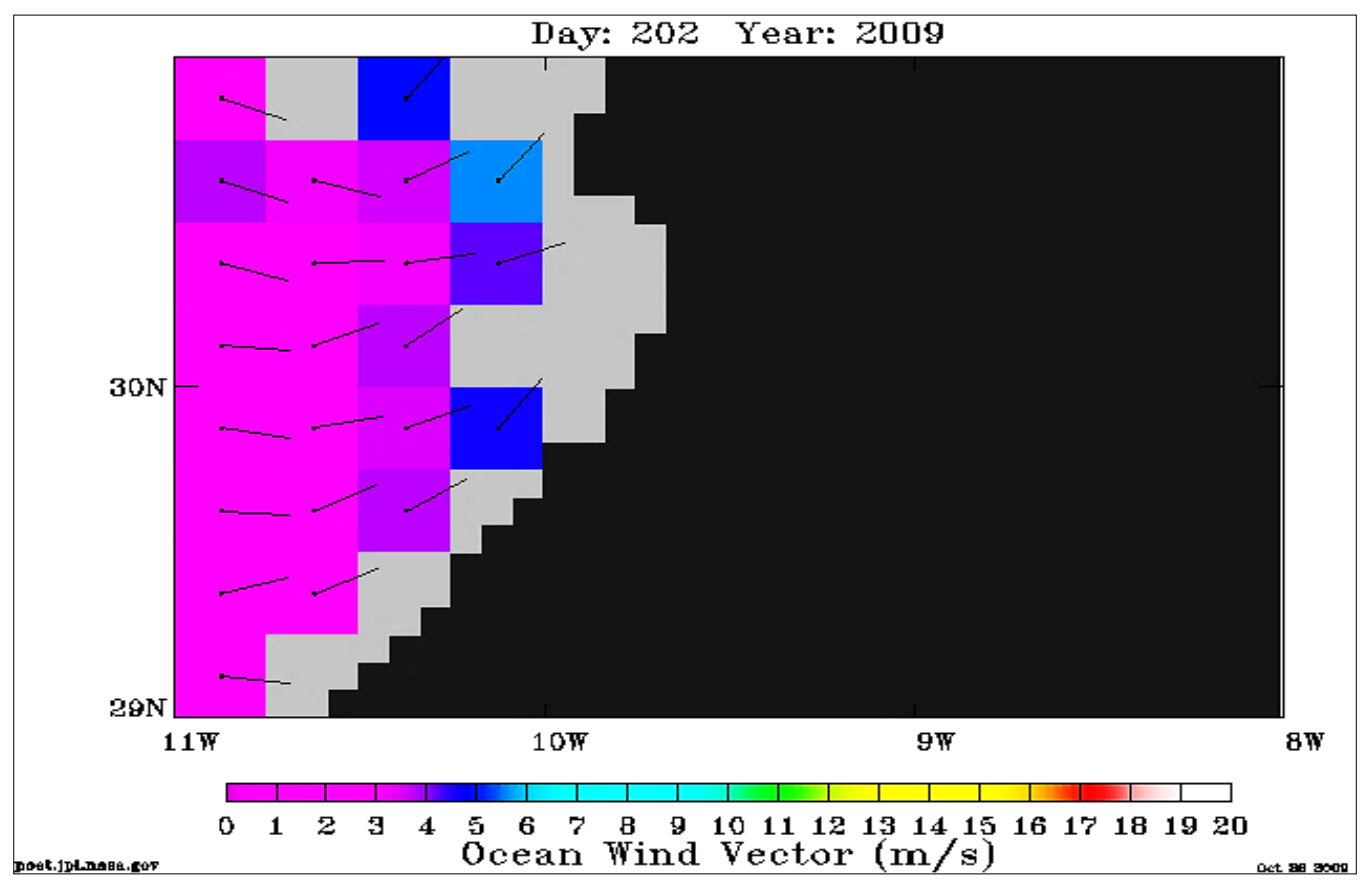

Figure 4:- The direction and speed of wind in the site Imessouane during July 21 st. (http://podaac-tools.jpl.nasa.gov/)

\section{Quantitative study of the zooplankton communities:-}

Analysis of the spatial and temporal distribution of different groups of zooplankton shows the dominance of copepod species and larval stages. (Figure 6).

The zooplankton densities recorded during our study are much more important than those cited in work concerning the Moroccan Atlantic coast. The maximum abundance of the Copepod in our site is of $405000 \mathrm{ind} / \mathrm{m} 3 \mathrm{at}$ the end of July. The coast of Eljadida, recorded a maximum abundance of 900 ind $/ \mathrm{m} 3$ during the summer [13, 14]. Also in the MoulayBousselham lagoon, the maximum density recorded during the summer is $16,000 \mathrm{ind} / \mathrm{m} 3$ [15].

The dominance of copepods in our results is confirmed by the other work carried out on the Moroccan coast that has recorded the same result. $[16,17,18,15,14,19]$.

In the scientific literature, the abundance of copepods in the Moroccan Atlantic coast is highest in the summer than in the spring[20]. This confirms our results during the summer, except for low densities of copepods that we recorded on 21 July. These can be explained by high levels of nitrite that were recorded during that time. The high levels of nitrites may be the cause of the sharp decline in abundances of zooplankton communities in our stations on this date(Figure 5). 


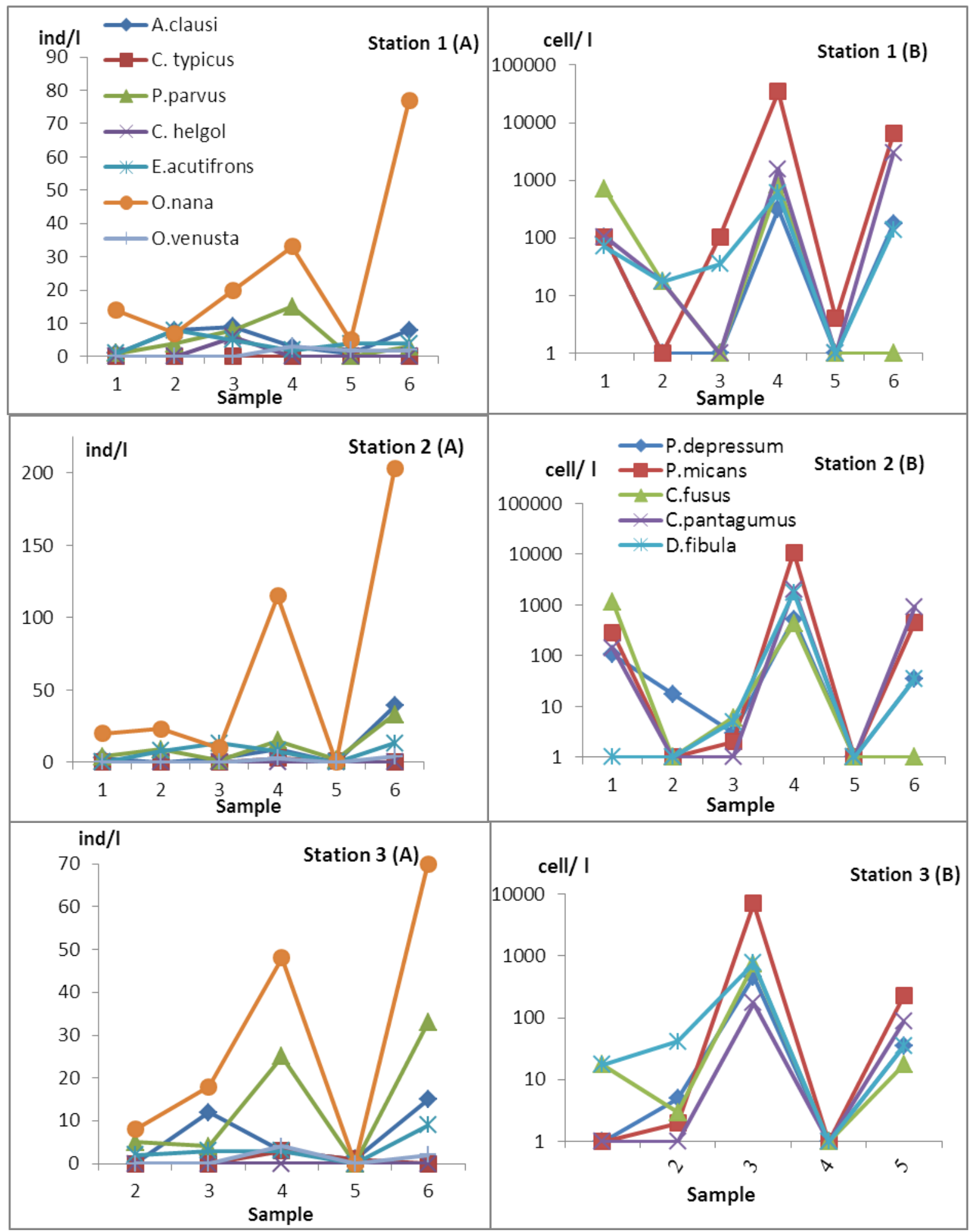

Figure 5:- Temporal and spatial evolution of each species of copepods (A) and phytoplankton (B) in our stations 


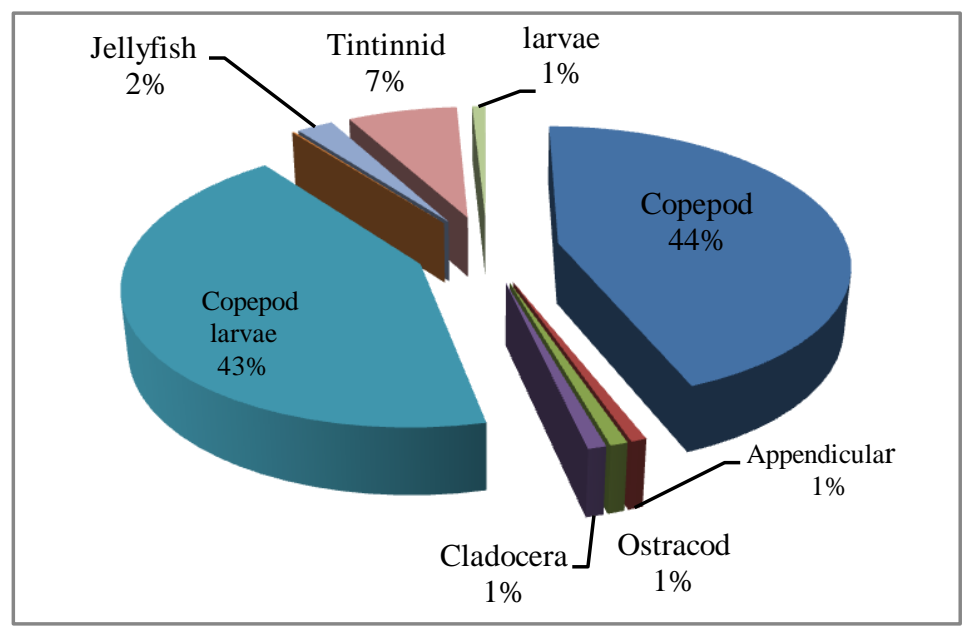

Figure 6:- Relative abundance of the different groups in Imessouane Bay

\section{Quantitative study of phytoplankton:-}

Analysis of the spatial and temporal distribution of five phytoplankton species shows that these species present of strong densities on June 30th (Figure 5), for the three stations. There are also more or less high densities at the beginning of May (May 7th) and at the end of July (July 31st). Procentrummicans is the most dominant species in this study, reaching maximum values during the June 30th $(\approx 10000$ Cell / L $)$. This species is cosmopolitan, essentially neritic and essentially marine.It can dominate the phytoplankton and cause colored waters. [22]. These species (ceratiumfusus, prorocentrummicans, protoperidiniumdepressum, Dictyocha fibula) are all harmful phytoplankton species,

Are all harmful phytoplankton species, which are responsible for phytoplankton blooms (colored waters).[22]. On June 30th, The Imessouane bay has a strong phytoplankton production dominated by the harmful species responsible for the colored waters.

\section{Principal component analysis:-}

We present below the CPA's results for the period of study in which we observed a variation of parameters taken at the three sampling stations. In the space of variables, the axis FI totals $65.05 \%$ of the total variance. On the one hand, it is positively correlated with temperature $(\mathrm{r}=0.936)$, dissolved oxygen $(\mathrm{r}=0.968)$, ortho-phosphates $(\mathrm{r}=$ $0.977)$ and nitrite $(r=0.664)$ and on other hand it is negatively correlated with salinity $(r=-0.208)$. The FII axis totals $34.95 \%$ of the totals variance. It is positively correlated with salinity $(r=0.978)$ and nitrite $(r=0.748)$. This high correlation, allow to consider the FII as an axis of degree of richnessin salinity and nitrite.The FI axis distinguishes the two stations 2 and 3. In effect, the station 2 is characterized by high levels of orthophosphate compared to the station 3, which confirms the values measured at these stations 19th May and June 30th.For the axis of nitrite FII, the effect of nitrite intake is particularly felt at the station 2.

In conclusion, the PCA has identified the factors responsible for the difference between the three stations namely nutritive elements (Figure 7).

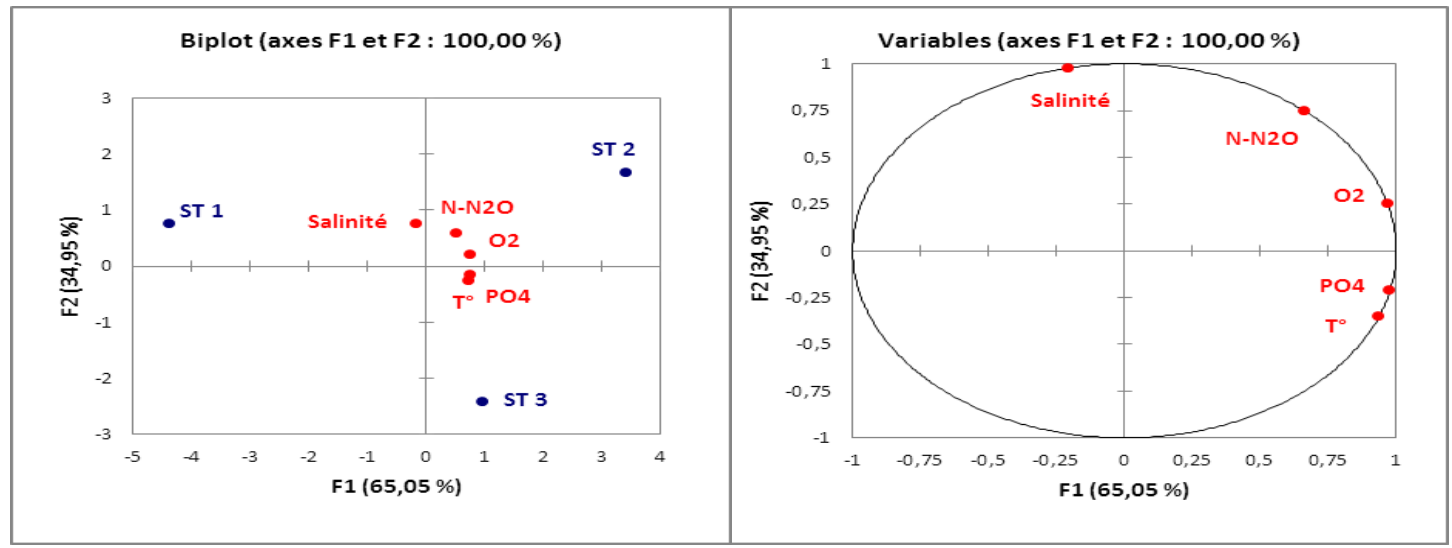

Figure7:- Results of the CPA during study period, andthe projection of variables (Physicochemical) and stations 


\section{Relationship environmental parameters community structure:-}

The canonical correspondence analysis was carried out on 13 species, the most represented in our study siteand 17 samples resulting by the net of $200 \mu$ with the depths of $10 \mathrm{~m}$. This analysis highlights different regroupings (figure 8); with a total inertia on the two axes $90.60 \%$ broken up into $54.06 \%$ for the axis F1 and $36.00 \%$ for the axis F3.

The first group is represented by four species of copepod, brings clause calanussp, centropagestypicus, temorastylifera. This grouping is more abundant in the summer than in the spring period. So itismuch more influenced by season.

The influence of nitrite on some species is the source of another grouping characterized by the strong predominance of the species Oithona nana. This group includes Oithonasimilis, Temorastylifera, clausecalanus sp. These species recorded maximum abundances July 21st,the date thatthe nitrites reached significant levels.

We note here a discrepancy of these results with the results of sampling by the bottle, in which a negative correlation was recorded between high levels of nitrites and abundance of species, specifically the four species mentioned before.

At the tropical Atlantic Ocean two maximum nitrite type can be met. The secondary peak located in the deeper layers, it is always linked to waters with very low oxygen levels, and the primary maximum encountered everywhere in the tropical Atlantic associated with the phenomenon of the thermocline [22]. Also the nitrite content is maximum at the base of the thermocline [23], with 10 meters of depth. Sameoto (1986) [24]showed that the vertical profile of the abundance of planktonic species has very low abundances at $10 \mathrm{~m}$ of depth for the surface thermocline, and it marked a strong presence of species of Oithona above the thermocline zone. This confirms our results and shows that all variations have been recorded on July 21 st may be due to the occurrence of this phenomenon.

The second grouping consists mainly by the copepod species that are almost in all samples and throughout the study period (paracalanusparvus, oncaeavenusta, acartiaclausi, jellyfish and siphinophore)

Species of Euterpinaacutifrons and Evadne are more represented in the samples (R1S1, R1S2, R2S1, R2S2 and R4S2). These samples contain significant amounts of nutrients (PO4 and NO2).

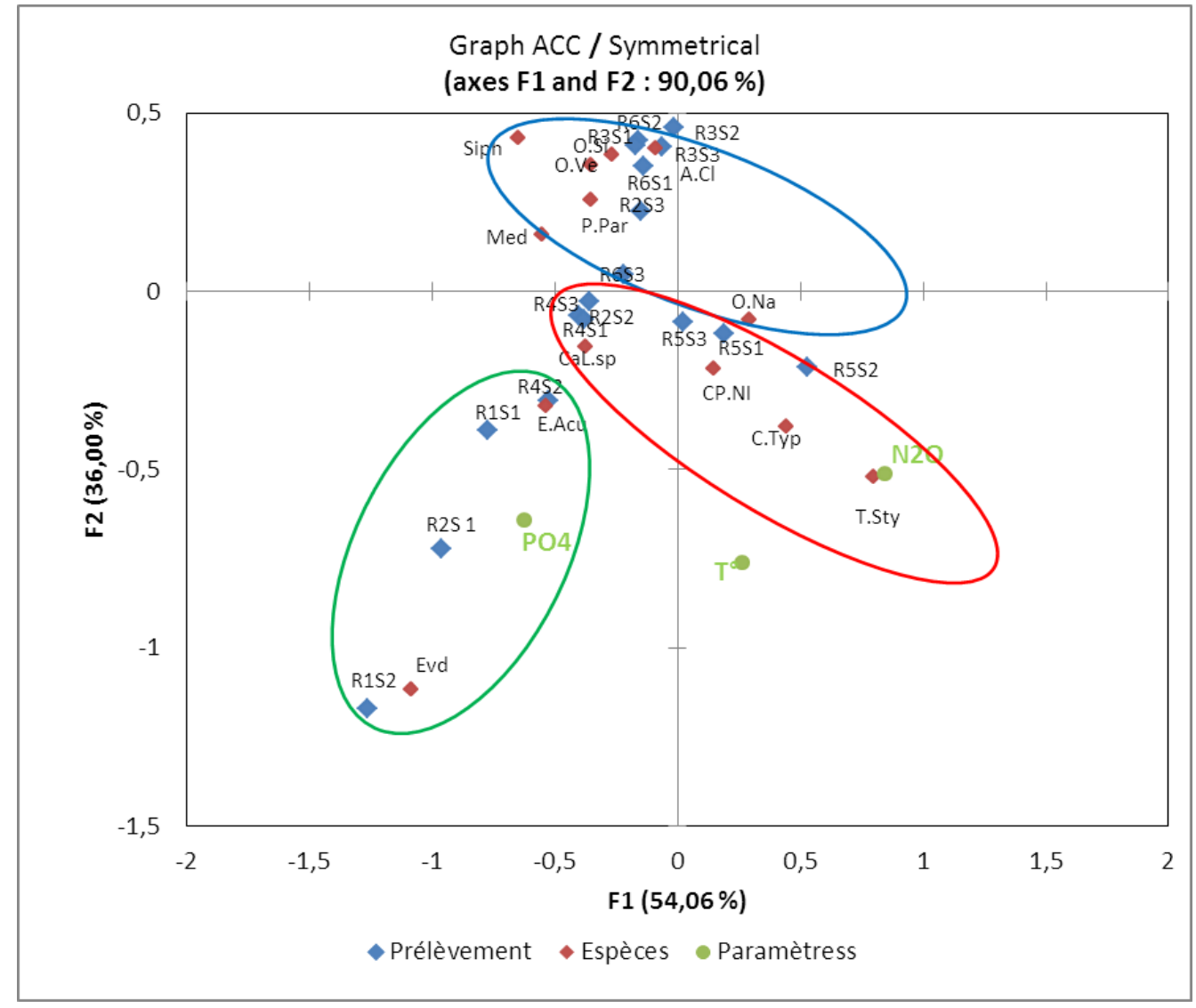

Figure 9:- The canonical analysis of the correspondences for the zooplankton species most represented in our study site 


\section{Conclusion:-}

Throughout this study, we tried to understand the spatial and temporal variation of the planktoniccommunities of Imessouane bay, also highlight the relationship between biotic and abiotic parameters.

The analysis of physicochemical parameters shows that some environmental parameters are essential to the functioning and in the spatiotemporal evolution of the planktonic communities. These parameters include the nutritive elements (nitrites, phosphorus), hydrology and the temperature.

The Copepods constitute more than $80 \%$ of the zooplankton communities. The species of oithona nana has an absolute dominance during the study period in the three stations.

The phytoplankton species have maximum abundance during the summer, especially at the end of June where there are blooms of some species of harmful phytoplankton (Ceratiumfusus, prorocentrummicans, protoperidiniumdepressum, Dictyocha fibula).

The Nitrites recorded a maximum level (July 21st) at the 10 meters depth. Low abundances of plankton populations are recorded at this depth. Above this area, high abundances of some copepod species are recorded. These results seem to be an indication that brings us to the phenomenon of surface thermocline.

Analysis of hydrological parameters by the use of the principal component analysis has identified the factors responsible for the difference between the three stations as the nutritive elements (nitrites, phosphorus).

The relationship between environmental factors and community structure was analyzed by canonical correspondence analysis. This analysis allowed us to structure the ecologic communities in three different groups. The first group (clause calanussp, centropagestypicus, Temorastylifera) is more abundant in the summer than in the spring period. The second group present in all samples, and throughout the study period (paracalanusparvus, oncaeavenusta, acartiaclausi, jellyfish and siphinophore).

The species Oithona nana, Oithonasimilis, Temorastylifera and clause calanussp, are more sensitive to the high concentration ofnitrites.

The last group includes species Euterpinaacutifrons and Evadne whichhave an affinity for nutritive elements (PO4 and $\mathrm{NO} 2$ )

\section{Reference:-}

1. IKZARN, A., 1986. Contribution à l'étude de la pêche artisanale sur la côte atlantique marocaine (d'Agadir à Imessouane) mémoire de troisième cycle. Inst Agro et Veterin Hassan II, Rabat.

2. Makaoui, A., Orbi, A., 2005. L'upwelling de la côte atlantique du Maroc entre 1994 et 1998, Océanographie (Géologie marine), C. R. Geoscience 337 (2005) 1518-1524.

3. ROY, C., 1991. Les upwellings : le cadre physique des pêcheries côtières ouest-africaines, in : Pêcheries ouestafricaines, Éditions Orstom, 1991, pp. 38-66.

4. Makaoui, A., Orbi, A., 2005. L'upwelling de la côte atlantique du Maroc entre 1994 et 1998, Océanographie (Géologie marine), C. R. Geoscience 337 (2005) 1518-1524.

5. Stempniewicz, L., Bachowiak-Samoyk, K., Jan. M. W., 2007. Impact of climate change on zooplankton communities, seabird populations and arctic terrestrial ecosystem a scenario, Deep-Sea Research II 54 (2007) 2934-2945.

6. EL OUIZGANI, H., 1994. Contribution à la modélisation de l'écosystème pélagique d'une zone d'upwelling le cas du Maroc, thèse de doctorat université paris 5.

7. TerBraak, C. J. (1986). Canonical correspondence analysis: a new eigenvector technique for multivariate direct gradient analysis. Ecology, 67(5), 1167-1179.

8. Bougis, P. (1974). Ecologie du plancton marin. 1: phytoplancton. collec/ion d'écologie.

9. AYADI, H., 2002. Etude qualitative et quantitative des peuplements phyto- et zooplanctoniques dans les bassins de la saline de Sfax, Tunisie, Revue des sciences de l'eau ISSN 0992-7158, 2002, vol. 15, no 1 (424 p.) [Document : 13 p.] (17 ref.), pp. 123-135 [13 pages].

10. Harris, E. (1959). The nitrogen cycle in Long Island Sound. Bull. Bingham Oceanogr. Collect, 17(3), 1-65. 
11. REDFIELD, A. C.et Keys, A. B., 1938. The distribution of ammonia in the waters of the golf of Maine. Biol. Bull., 74, 83-92.

12. KRAUSE, HR., 1964. Zu chemie und biochemie der Zersetzung von Susswasser-organisme, underbesonderBerucksichtigung des Abaues der organschen Phosphorkomponenten. Verh. Int. Ver .Limnol., $15,549-561$.

13. Chiahou, B., \&Ramdani, M. (1996). au cours d'un cycle annuel. Mar. Life, 6(1-2), 21-25.

14. Chiahou, B., \&Ramdani, M. (1997). Systématique et distribution saisonnière des copépodes pélagiques de la côte atlantique marocaine (région d'El Jadida). J. Rech. Océanogr, 22(3), 75-80.

15. BENBAKHTA, B. 1994. Structure et dynamique du zooplancton de la lagune de Moulay

16. THIRIOT, A., 1978. Zooplankton communities in the West African upwelling area. In: R. Boje, M. Tomzak (Editors). Upwelling Ecosystems, New York, pp. 32-61.

17. BELFEQUIH, M., 1980. Les copépodes du plateau atlanto-marocain. Un cycle annuel dans les zones d'upwelling. Thèse3eme cycle, Université Aix-Marseille I, 126 pp.

18. BOUCHER, J., 1982. Peuplement de copépodes des upwellings côtiers nord-ouest africains. II Maintien de la localisationspatiale. OceanologicaActa, 5(2): 199-207.

19. CHIAHOU, B., RAMDANI, M., MENIOUI, M. 1998. Structure biogéographique des copépodes des côtes marocaines. Rapp. Comm. int. MerMédit., 2, pp. 406-407.

20. SOMOUE, L., ELKHIATI, N., 2005. Abundance and structure of copepod communities along the Atlantic coast of southern Morocco, ACTA ADRIAT, 46 (1): 63 - 76, 2005

21. BENNOUNA, A., 1999. Etude du phytoplancton nuisible et de son environnement dans la lagune de OUALIDIA et SIDI MOUSSA (Maroc), Thèse des études supérieures.

22. Vaccaro, R. F. (1965). Inorganic nitrogen in sea water. Chemical oceanography, 1, 365-408.

23. BALVAY.G, (1992), Distribution vertical du zooplancton dans le Léman en 1991, rapp.comm.int. prot. Eaux Léman contre pollut., 115-125.

24. SAMEOTO. D., HERMAN. A., LONGHURST, A.1986. Relations Between the Thermocline Meso and Microzooplankton, Chlorophyll a and Primary Production Distributions in Lancaster Sound,Nova Scotia B2Y 4A2, Springer-Verlag 1986,Canada. 